\title{
Religion and Politics in Eastern Kurdistan (With a Focus on Maktab Qur'an During Iranian Revolution, 1979)
}

\author{
Sabah Mofidi ${ }^{1}$ \\ ${ }^{1}$ Justice Administration's Institute for Law Education, Scientific-Applied University, Sine (Sanandaj), Kurdistan, \\ Iran \\ Correspondence: Sabah Mofidi, Justice Administration's Institute for Law Education, Scientific-Applied \\ University, Sohravardi Square, Sanandaj, Kurdistan, Iran. E-mail: mofidi.sabah@gmail.com
}

Received: April 26, 2015 Accepted: June 5, 2015 Online Published: July 4, 2015

doi:10.5539/jpl.v8n3p36 URL: http://dx.doi.org/10.5539/jpl.v8n3p36

\begin{abstract}
This article studies the political function of religion in Eastern Kurdistan (Iranian Kurdistan) during the Iranian revolution, 1979, and early years after its victory. It tries to answer the questions as; what is the effect of ideological hegemony of religion and its conversion to a political tool on the political issues of Kurdistan? And whether the religious ideology is a factor to solidarity or disintegration among Kurds? It clarifies the understanding of political groups on their society as a traditional society and the circumstances related to the time and place. In this regard, the function of Maktab Qur'an (Qur'an School) as most important Islamist trend at that time is examined. Besides, the stance and the approach of central government, some groups and main parties in Kurdistan in relation to religion are studied. This paper also makes an attempt to study the Islamist idealism and the ideological conflict between religion and left movement, its results and effects on Kurdistan's events.
\end{abstract}

Keywords: Iranian revolution, Kurdish nationalism, left movement, Maktab Qur'an, politics, religion

\section{Introduction}

Religion in traditional society plays a pivotal role and it interferes in all spheres of societal life, while in modern society, religion has lost some of its traditional functions. The uprising of secularism led to the outbreak of an impartial institution (state) which resulted out of the prior conflicts and wars experienced under religion. Despite this, the relationship between religion and politics still seems to co-relate and had increased beyond limitations, though temporarily, because of the advent of the political religion as a weapon for the religious actors in the entire realm of socio-political issues during the third $\left(3^{\text {rd }}\right)$ world societal phase. This can be justified by looking back at some of the noteworthy and revivalist movements such as the Iranian revolution (1979) and the extension of Islamic fighting in Middle East etc, that has been marked for its great impact on religion and politics and is mentioned as 'reaction to the creeping secularism' which have been regarded in political studies. However, the issue of the effect of religion on political subjects is one of the fields related to Kurdistan that has, by far, been neglected.

In the Kurdistan uprisings during history, religious figures have played an important role. Most of the classic political developments and evolutions resulted with the leadership of the religious figures. In new political movements also we can notably reckon their tremendous service and efforts contributed in the course of the formation of Kurdistan Republic in 1945 and also after the Iranian revolution (1979). Moreover, the non-religious forces to legitimize their activities, powers and mobilization of masses recruited clergies' supremacy. For example, during Kurdistan Republic, there was no conflict between the religious and the non-religious groups as in the present scenario, but it was only with the coming of Qazi Mohammad as a religious national leader that the J.K party (Note 1) (later, Kurdistan Democratic Party), started its apparent activity. And along with it, during the 1979 revolution of Iran, Sheikh Ezzadin Husseini, a famous and top clergy in Mahabad, was the mediator between different forces in Kurdistan. Nevertheless, the Kurdish movement couldn't use the firm religious sentiments of the mass, as potential in favor of Kurdish question effectively. Hence, it has often been used by the central powers in all countries including Kurds (Mofidi, 2005). The apparent view of this situation is the pivotal functions of the political actors in Kurdistan political arena during the Iranian revolution (1979) emphasizing more on the sensitive time which was the crux of the hour for 
Kurdistan politics.

Apart from Kurdistan Democratic Party of Iran (PDKI) which was the main political party in Kurdistan since 1944-5, during the revolution some other organizations and trends were formed and appeared such as 'Komala', a Marxist-Leninist and Maoist organization declared formally in 1978-9, Maktab Qur'an trend under Ahmad Moftizada, the organization of 'The Community for Defense of Liberty and Revolution in Kurdistan,' Rizgari party, some branches of Organization of Iranian People's Fadaiy Guerrillas, Tudeh Party of Iran, and so on. Beside these organizations, we can mention Shiekh Ezzadin Husseini, the religious-national leader of Kurdistan who almost acted nonpartisan. Among these effective actors in Kurdistan, this article examines the role of Maktab Qur'an trend. In this regard, first, it is necessary to have a short look on the theoretical discussions about religion and its functions.

\section{Religion and Its Functions}

Some definitions of religion are substantial that they discuss on the essence of religion. The others are functional and explain what religion can do. In Auguste Comte's view, religion not only is an attempt to clarify and recognize the reality, but also is a basis for uniting the human society. The Durkheim's definition also includes a functionalist element since it mentions that religion unite and solidify its follower in a single ethical society (the theory of religion and correlation). The functionalist definitions are usually depended on a theoretical perspective that wants to clarify the religion based on an inducer basic role (Hamilton, 2001).

The new functionalists have entered a strong psychological element into a sociological approach. Religion reinforces the individuals to consider the grouped norms and prefers them to the private interests. It helps the social solidarity over the trips, communities or nations (ethnicities) (ibid.). This function is used in politics. In this respect, religion with deep social roots has an extraordinary power to mobilize the society. According to John Paul Willem, it makes a social identity because of its cultural influence. When some of the people see their benefit in expressing their identity by religion, religion is found as a factor to mobilize masses (Sheikh Attar, 2002, 29).

But, it should be noted that religion is a sectarian force as well as a solidarity factor. Religion is not always an integrator. Sometimes religious beliefs cause to anti social behaviors and disorder. Religion integrates a non-just society as well as a just society, such as most of Islamic countries. O'Dea mentions 6 dysfunctions of religion out of which three (3) of them are relevance here: conservatism and prevention of adaptation to changing circumstances, utopianism and inhibition of practical action, conflict among groups and prevention of adjustment (Hamilton, 2001, 138).

In the modern age, based on the distinction of experts, religion has lesser social functions. But in traditional societies, especially among Muslim, it still interferes in all affairs. In domain of politics, Islam has a various roles and functions from legitimatizing and supporting the status quo till protests and providing a ground for revolutions. According to Sarie A-Qalam, an Iranian writer, "The deference between Islam and Christianity and oriental religions is that Islam is strongly political and has political formats and it is not summarized in Christian and Confucian ethics. Islam is the idea that strongly makes relationship between religion and politics" (Sheikh Attar, 2002, 3-5). However, religion is used as a tool by both government and its opponents. With this theoretical background, let us take into the core of Kurdistan political scenario and discuss how politics and religion function and administer in this region.

\section{An Overview on Political Activity of Kurdish Clergies}

In Kurdistan until 1979, there were no special religious fights. This was not due to the air of disbelief among the people. The main root of this issue has to be sought in national suppression and Kurdish nationalism. The fighting was always based on the nationalistic issues and not on religious front which surpassed the channel of national question. In anti-colonial and anti despotism fighting, the national element has had the organizing role. If in the past period the religious figures participated in fighting and even were in the top of it or as the leaders, the reason was their support of national question. In this respect, Chris Kochera mentions three stages in Kurdish movement; feudal, religious and political stages (Kochera, 2000). In every stage, a special class has led the movement, but their common aspect is the national question.

The leadership of most of classic Kurdish movements was under the religious figures as Sheikh Obeid-O-Allah, Sheikh Reza, Sheikh Mahmud and so on. The remarkable and active role of clergies in new movements on both leadership and organizational levels is also a witness on the role of religion in Kurdistan and the relationship of religion and politics or indeed of religion and nationalism. For example, Mamosta Abdurrahman Lahijani, a member of PDKI, in an interview while narrating his memories, mentions that; 
... A day, a religious student came to me from Mahabad and told me that I have been invited to Mala Hasan Qezelchi and Mala Mohammad Torjanizada. I was delighted and went together.... They asked me to have a trip to Iraqi Kurdistan and visit Sayed Hussein Huzni in the Ruwandiz town .... Early summer 1932, three other students and I went there. I introduced myself to Sayed Hussein and I told him the password to ensure.... For 6 months every Friday, we were taught in Kurdish nationalism and political lessons and then we returned Iran. And we gave Qezelchi, Torjanizada and Mala Ahmad Fawzi, his order and teaching (A castle of will..., 2003, 38).

There are many of such examples of mosque's activity in Kurdistan, especially the activity of students and clergies in J.K party like Qazi Mohammad, Hajar, Hemin and so on. In addition to that, we can mention the activity of Ahmad Muftizada and Hasan Amini, the leaders of Maktab Qur'an that a part of their life had been dedicated for nationalist activity. When Moftizada was young, he had a trip to sought Kurdistan (Iraqi Kurdistan). It reinforced his nationalist sense that has lasted until 1963. Hasan Amini also, according to himself (2006), was a member of PDKI until he got familiar with Ahmad Moftizada.

Such activities of clergies or strong vibe of national feelings among the students related to national question continued over Kurdistan. The activities during Kurdistan events after 1979 revolution, is another example of the role of clergies. Such as the conference of religious leaders of different cities of Kurdistan on March 17-18, 1979, where in, a three point articles manifest, suggested the Kurdish nation's demands. It was signed by Sheikh Ezzadin Husseini, Sheikh Jalal Husseini, Ahmad Moftizada, Mala Mohammad Rabeei, Mala Abdulla Mohammadi and.... However, due to the changes and development of the social structure and the growth of the city's population, the activities of the clergies were mainly focused on the urban areas. Villagers almost remained as a supporter of traditional clergies but in cities and towns with the youth's tendency to new interpretation of Islam, the people were attracted by new Islamic trends such as Maktab Qur'an and Muslim Brotherhood. This change in Eastern Kurdistan especially Kurdistan province was remarkable. Thus, the combination of urban movement gratified by Islamic approach and the activities of the traditional clergies together mounted as a powerful rival for other forces in the political arena.

\section{Religion as a Political Tool of Central Government}

The Kurdish nationalists especially in new Kurdish movements did not use the political functions of religion well. On the other hand, simultaneously the extremist left trends in such traditional society grew without localization of their thought, and were not mentally and strategically alert which led to attack on religion. All these issues paved way for the central governments in all countries including Kurds and particularly Iran to use religion against Kurdish movements. During early years after Iranian revolution, 1979, despite of the deep religious cleavage, religion was used as a means to debilitate the Kurdish nationalist movement in Eastern Kurdistan, especially through encouraging and reinforcing the religious forces against left forces. And the government tried to remove the Kurdish question and covered the national right of Kurds under this conflict. As a result of this contradiction and government's use of religion, we can mention the forming of Kurdish Muslim Fighters Organization (Note 2) within one of the biggest Iranian military organizations, the Islamic Revolutionary Guards Corps of Iran (IRGC) (Note 3).

In the subsequent parts, such ideological-political cleavage between the left and religious trends and centre's use of religion will be revealed well. Here, in order to have a clear knowledge about it, we just mention some leaders' stances. For Ayatollah Khomeini, the super leader of Islamic revolution, the war of Kurdistan was the war between Islam and heresy. For instance, in his announcement about the events of Kurdistan, published in Kayhan newspaper, March 18, 1979, he called the action of Kurdish people and their parties as an action against Islam and the security of Muslim. And he named any attack against the government's army as the action of non-Muslim and foreigners which must be removed strongly (Khoshali, 2008). Besides, let us see what Ibrahim Yazdi, the foreign minister of the provisional government (1979), had mentioned about the centre's use of religion. This context relates to the aftermath of the revolution's victory, that shows the religious policy of central government in Kurdistan. In an interview with Ashti Newspaper (2005), he says:

About Kurdistan, we believed Islamic revolution has not root there in contrary with other parts of Iran since in Kurdistan the history of the non-religious or anti religious activity of left groups has been more than other groups. So we thought, first, the revolutionary culture have to transfer into Kurdistan. Accordingly, we sent some of youths there to do cultural activities. Through the help of some Kurdish friends who we had cooperation together before the revolution like Dr. Mozafar Partomah, some Islamic books such as the works of Mawlana Abu Ala Mawdoodi translated to Kurdish, were published in Kuwait, and were contributed in Kurdistan. Indeed, we thought that the cultural movement and 
changing have to exist in religious views of Sunni brothers too. Secondly, we knew that the left parties in Kurdistan are active but they are in minority. Hence, we sought a way to connect with the main body of society and the majority of people.

After the first stage of revolution's victory, we can see such stances too. Banisadir, the first president of Iran, before his presidency, when he was in the Bazergan's cabinet, in a speech in Khorram Abad talking on Kurdistan and Sine (Sananadaj) city council election, divided Kurdish people into Muslim and non-Muslim. According to Jemhori Islami newspaper, October 22, 1979, he said: “...however, out of 11 elected members, 8 persons are from Muslim and 3 are from them [non-Muslim], so the winner was Muslim and the problem was finished...." During his presidency, according to Kayhan newspaper, April 3, 1980, in the first congress of Islamic revolution, addressed the Kurdish militant groups and said: “...It is intolerable for the Islamic Government that Islam becomes strange in Kurdistan. For our Muslim people, it is intolerable that being Muslim becomes a crime in Kurdistan ..." (Khoshali, 2008).

\section{Extremist Left and Conflict with Religion}

Although the new Kurdish national movement has often been influenced by left thought, still there were some groups, who because of their ideology had misinterpreted the socio-political situation of Kurdistan and fell into conflicts with religion during the sensitive period of Kurdistan's political history after the Iranian revolution, 1979. Therefore, they provided a ground to use religion against themselves by central government. These groups that practically defined politics in the line of their ideology, not only were paralyzed to help themselves but also ignited reaction of some contradictory trends, especially the Islamic ones. They couldn't attain the necessitous mass support because, their main problem was not the Kurdish question and the right of the nation, but also the traditional society of Kurdistan didn't have the considerable factors of Marxist-Leninist movement that included both the capitalist society and industrial workers. Moreover, Kurdistan's rural society was also under the effect of religion. So in theoretical sense, they didn't have the power of localization of left thought.

Some of these groups, though close to Sheikh Ezzadin Husseini, as his office was composed from members of Komala organization at that time (Kochera, 1999, 63), were strongly anti religion. As a result of which they accused PDKI with the instance that, their stance about Islam is not clear and told; "Talking with us, they tell we want socialism, but every Friday a clergy has speech in their radio speaking on Islam." Besides, after the entry of PDKI into National Council of Defense (an Iranian opponent organization), Komala criticized them and claimed they have accepted the principle of Islamic Republic on the light of the council's document which mentions Banisadir as president of Islamic Republic (ibid., 94). Apart from this, the conflict of this left groups (Tudeh, People's Fadaiy Guerrillas and Komala) with Maktab Qur'an trend clears the ideological-political cleavages that indeed provided a ground for the policy of using the conflict or 'divide and rule' policy by central government that will be explained as the paper advents.

\section{The Moderate Organizations and Compatibility with Religion}

Apart from the left and Islamic forces, the nationalists are the third dimension of the triangle of political forces in Kurdistan. These moderate organizations were not against religion nor did they use religion as a political tool on large scale. They didn't want to mobilize the religious sense of mass against themselves despite of being non-religious or left. So, the political conflict between religious and moderate forces didn't lead to the advent of the discursive debates between Islam and nationalism. In fact an amble reason might be the common area and national rights that they shared between themselves as Kurdish people since the Kurdish question was also important for religious forces, though it was in second degree after religious problem. These groups didn't use religion as a tool, but they were aware of their own traditional society.

The PDKI has been an important moderate party. This party in its plan for Kurdistan's autonomy, published in Ettlaat newspaper, March 3, 1979, regarded secularism including separation between state and religion, freedom of religious belief, equality before law for all religions and the lack of racial-religious discrimination (Khoshali, 2008). Its political policy and strategy, 'Democratic Socialism', has been a moderate idea in contrast to the extremist left and religious conservatives. For example, we can mention the stance of the party ex-leader, Abdul Rahman Qasemlu, about Islam. Although he and his party believed in 'democratic republic', considering the country's political space, in a speech, published in Ettlaat newspaper, February 22, 1979, he had said: "The Kurds' demand is simply resolvable under an Islamic Republic. Our demands is such that any revolutionary government especially the current government on power cannot reject them" (ibid.). And later this party's opposition to 'Islamic Republic' and boycotting its referendum by them was because of the vague content of this term. Moreover, in an interview with Ettlaat newspaper on March 31, 1979, about the party's relationship with religious figures in Kurdistan, he says: 
Our attitude with any leader and political figure is very simple. If this religious or political leader defends the interests of Kurds and other Iranian nations, and acts in the framework of our major slogan 'democracy for Iran and autonomy for Kurdistan', the party will cooperate with this religious and political leader. About the current religious leaders, until now I didn't visit Mr. Moftizadeh and I don't know him but our opinion on Ayatollah Ezzadin Huseini has not been changed and he possesses the competency for leading the Kurdish representation in negotiation with government (ibid.).

In the resolution of Democratic Party presented by its representative in Sine conference leaded by Moftizada (though the party itself didn't participate since they were not advised by Moftizada earlier), and published in Ayandegan newspaper, June 13, 1979, mentioning the right of autonomy and federative for Kurdish nation and other nations, it had been said that, '...What is important for Kurdish nation, is not the name of 'Republic.' Its content is important. If Islamic Republic accepts the basic demand of Kurdish people [autonomy for Kurdistan and democracy for Iran], doubtless Kurdish people will support it" (ibid.). In an interview with Kayhan newspaper, on November 27, 1979, he says:

...The Kurdish nation has upraised against neither Islam nor Islamic Republic but has defended their rights, and they, [central leaders], should defend the Kurdish right based on their Islamic, Humanity and national task. [...] we not only have not anti Islam belief but also as you can see the majority of Kurdish people are Muslim and our party has come out from depth of Kurdistan society, most of our members are Muslim, they have depth belief to Islam's tenets. We also as a political party believe in this depth belief of Kurdish people ... (ibid.).

In another interview with reporters about the relationship between Islamic Republic and autonomy, published in Ettlaat newspaper on March 10, 1980, he had mentioned that: "what is important for us is the content of Islamic Republic. If it secures our wills, we will remain inside its framework. What we understood from Imam's words yesterday and we are also of the opinion that there is no conflict between autonomy issue and Islamic Republic regime" (ibid.). Besides, in his address in Mahabad, Qasemlu talks on autonomy as following:

... Two days ago Allameh Noori, the absolute representative of Banisadr for negotiation in Kurdistan, sent a message to us that within which he says, if along with the word 'autonomy' that is interested by Kurdish nation, the word 'Islamic' also will be added, what is your opinion? Here, we announce that the majority of Kurdish nation are Muslim and if the Islamic autonomy will be vested, the Kurdish nation will accept and will be happy (Qasemlu, 2004, 359).

According to his interview with Iran Farda on June 18,1979, Qasemlu believed that for cleaning and construction, all anti imperialist forces in Iran, the original revolutionary forces - religious and non religious- must really be united each other (Khoshali, 2008). However, if the religious trends were in alliance with moderate trends and they had flexibility in this sensitive condition, it could be in favor of Kurdish question, on the one hand, and it could prevent the ideological-political conflict that was in favor of central government, on the other.

\section{Maktab Qur'an and Political Issues in Kurdistan}

In Kurdistan, some groups brought religion into political game, despite of the little applicability of the political function of religion in the line of Kurdish rights. One of the first and important groups was Maktab Qur'an, founded by Ahmad Moftizada. They are known as 'Maktabi' or 'Kak Ahmadi' in Kurdistan. Here, we briefly explain this trend and its political ideas and activities.

\subsection{Ahmad Moftizada and the Formation of Maktab Qur'an}

Ahmad Moftizada (Note 4), well known as Allameh Moftizada or kak Ahmad, the leader and founder of Maktab Qur'an trend, was born in 1933 in Sine (Sanandaj) in a religious family. From his childhood, he was an ardent believer and follower of religious stance and he attained religious sciences. In 1948, he went to Mariwan for learning Arabic literacy and Islamic sciences, which later in 1949, he went to southern (Iraqi) Kurdistan for the same intention and stayed there for 2 years that rather reinforces his Kurdish nationalist sense. When he attained his 17-18 years, his father sent him, as a teacher, to Dar-Al-Ehsan school in Sine. He also presented a series of discussions and speeches before the Friday pray. In 1957-58, he went to Tehran and started working on Kurdish radio and Kurdistan newspaper. In 1959-60, he tried to found a department for jurisdiction of Quadripartite in law College of Tehran University. He also taught the methods of sects' jurisdiction and Islamic philosophy in law and theology colleges (An Exploration in Political Life..., 1985, 26).

In 1963, his radio program and Kurdish newspaper were banned and he was arrested for 5 months. In this year with the event of 15 Khordad (June 5) uprising in Tehran, his thought was changed. In prison, he became familiar with some Shiite revolutionary clergies. In 1964-65, he went back to Sine. In 1972-73, he was appointed 
as head of the writers' council of Sine radio. His activity in radio was stopped in 1974-75 and then he began working as a private business entrepreneur in a constructing company (along with some friends). In 1976-77, he undertook the responsibility of the Kurdistan Sharia court (likely non-governmental). In the same year, he founded the first branch of Qur'an School in Mariwan. After that in 1977-78, he founded the school in Sine and dealt with revolutionary questions. With the victory of revolution, he founded the revolutionary committee and settled in the office building of the governor of Kurdistan province.

On March 6, 1979, he founded the Islamic Musawat (Equality) Party. On March 18, 1979, he participated in the conference of Kurdish religious leaders in Seqiz (Saqqez). In June 10-12, 1979, he launched the conference of autonomy in Sine. Besides, in spite of canceling his candidacy in Experts Assembly (Majlese Khebregan) election by himself, he participated in the assembly after its formation. In September 1979, he conducted a series of addresses in Hosseinieh Ershad that was the beginning of new stage in his political life. He opposed with some principles of Islamic Republic of Iran's constitution especially the $12^{\text {th }}$ article that led to the formation of the 'Sunni Central Council' (Shoray Markazi Sunnat or ShMS) on March 31 and April 1, 1981. Through his invitation on March 13, 1981, the Sunni clergies and leaders participated in the Tehran conference that they enacted a 16 articles manifesto. On August 5-6, 1982, he launched the memorial of the foundation of council in Kermashan (Kermanshah). On September 9, 1982, he was arrested in Tehran and was taken to jail. After 10 years in August 4, 1992, he was released and in February 8, 1993, he passed away. Apart from speeches, articles and his poems, he has two important works: 'A Brief Discussion about Islamic Government' and 'About Kurdistan.'

\subsection{The Maktab and the Idea of Forming Islamic Government}

In contrary with the Islamic trends in other countries and regions, the Kurdish Islamists practically didn't support the Kurdish nationalism against pan-Iranism in the necessitous time and they supported central government since they tended towards political Islam very soon. It had two main reasons; firstly, the time of their activity coincided with the second stage of the political life of Islamic thinkers and trends, i.e. Islamism in some countries which had passed the nationalist stage (Note 5). So they were affected by Islamist climax of those countries. Secondly, in Iran, they were also affected by the current political Islam climax. Hence, for these reasons, the religious thought dominated on Kurdistan Islamic trends, in spite of being religious-national.

The disability of nationalist trends in the region (Middle East) in contrast with the ideological and organized power of Marxist trends like communist parties specially Toudeh (Mass) party in Iran, reinforced this claim of Islamists that only Islamic discourse could throw out the Marxism from the arena as a anti-religious and anti-national trend (Ahmadi, 2004-05, 80). It affected the religious trend of Kurdistan too. While the new nationalism in Kurdistan had been tied with left trends, the Islamic trends under the effect of political Islam in Iran stood against the left movement. This political stand was for attaining power. But this domination of religious dimension did not have a good end. In this regard, Hasan Amini, one of the leaders of Maktab Qur'an, in his interview with Chashmandaz magazine (2006), about the political fault of 'ShMS' council's activity mentions that: “... But unfortunately the officials of that time instead of listening to the demands and trying to fulfill them, they started to threaten and violence...." Thus, the Maktab Qur'an in the first years of the revolution's victory trusted to the central government instead of closing to Kurdish nationalists even if it was temporal and as a political caution. Therefore, it couldn't use its influence among mass to remove the national suppression and as its consequence removing the religious suppression also at least in this region.

Concerning to what was mentioned above, we should examine the hegemony of religious ideology in Moftizada's thought as an example of this hegemony in Maktab Qur'an trend totally. Here, considering some points are necessary;-

1) The religious suppression is not only related to Kurds, and it is not the main Kurdish Problem;

2) The Kurds are not just Muslim and Sunni, especially in Iranian Kurdistan the population of Shiite Kurds is high;

3) In Iran relying solely on a policy for reaching religious equality is not enough;

4) Removing religious suppression without removing national suppression is not possible and they are tied each other especially the Sunni Kurds have national-political awareness, so the domination of religious politics practically is not efficient;

5) The Moftizada's nationalist activity and later his thought of forming Islamic government is not comparable with Indian and Arab Islamic thinkers as they first passed the nationalism stage and got result in this regard or they used Islam in the line of nationalism, after that they started the mere Islamic movement. While the result of nationalist movement of Kurdistan still was not clear and didn't reach the target. 
Indeed, Moftizada diverted from his earlier notion of nationalistic view prior to 1960 s, which had to be done after the solution of Kurd's question. His nationalist aspect continued until 1963, till the time of his arrest, and after which his relation with 15 Khordad (June 5) uprising and some Shiite clergies developed. Albeit during these years simultaneously along with Kurdish nationalistic activity, he tried to remove superstition and deviations from Sunni and Shiite but the national (Kurdish) issues was more important for him. As he quotes, "I wished to serve suppressed Kurdish literary and language through both address, religious and literary debates and a Kurdish newspaper" (Moftizada, 1979a).

After 1963, his approach changed to Islamic idealism. In this respect, he states: "When the revolutionary fire was started in June, 1963, I was in Naser Khosro st., I saw the people's uprising and the King regime's crimes closely. The effect of the day's event had a great impact on my heart that changed my method entirely. Before that my intention was always targeted to fight with religious superstition and because of national suppression had been put down to serve the Kurdish culture, though I never had any inclination towards the struggles of Iran" (Moftizada, About Kurdistan, 158). In the manifesto of August 12, 1980, he mentions that: "And thanks to God that after several years, a situation was provided that I understood my old measures has been empty and superficial. From 1964, I decided to adopt the main way of Islamic revolutionary of prophet Mohammad... and from the same year, I reconciled my program with this way and I confined my work on movement towards the growth of scholastic (Maktabi) Muslims and propagating true Islam and reaching/preaching the message of Qur'an to alienated Muslims from the Qur'an" (An Exploration in Political Life..., 1985, 30). In an interview with Ettelaat newspaper on June 25, 1979, he described his intellectual changes as following: "In 1963 after the closure of Kurdistan newspaper, I was in Qezel Qal'eh prison for 5 months and later for continuing the fighting, I went back to Sanandaj. At this time I realized that Islam and nationality are not in contrast and I lay my fighting on this basis" (ibid., 31). Also, in another interview with Kayhan newspaper on June 15, 1979, answering a question on his stance against Democratic Party, he says "my stance was clear from several years ago even before 1963. My all attempts is for reviving the real Islam in Iran and abroad ..." (Khoshali, 2008).

In the constitution of Islamic Musawat Party (March 6, 1979) that includes the 6 articles written by Moftizada, the second article mentions that: "In Islamic society of Iran, the various social, cultural and political right of all Iranian Muslim nations have to be provided equally and based on executing the Islamic laws and rules precisely, they should have entire liberty within united Iran (it includes the other Muslim nations within the other countries). Based on this principle none of the Muslim ethnicities in any way has any privilege on others...." Article 5 also mentions that: "The membership of Islamic Musawat Party is not confined to a special nation, any people from anywhere and with every nationality that believe to these principles and wants to fight for executing them, can be a member of it." This constitution includes the Islamic Idealism and universalism, though it also mentions the right of nations. Therefore, it was not the realist view and it created a clear cleavage between them and the Kurdish forces and had a negative effect on Kurdish issue. In this line, Moftizada gave most significance to religious oppression (among three oppressions mentioned by him: religious, national and class) that its culmination was in protest and criticize the $12^{\text {th }}$ principle of constitution of Islamic Republic of Iran. According to the principle, 'the official religion of Iran is the Islamic sect of Jafary Esna Ashari Shiite that this principle is not changeable for ever ....' Hence, his idealist view and lack of political realism practically led his attempt in favor of religion (against nationality) and unwillingly it was in the line of political aims of central government. In respect to domination of the religious aspect in Moftizada's mind, Sheikh Ezaddin Husseini mentions that: "The difference between kak Ahmad and I is that he is a Kurdish Muslim and I am a Muslim Kurd" (The Bloody War of Sanandaj..., 1979, 132).

The priority of religious dimension in Maktab trend becomes more apparent in Moftizada's attempt for forming Islamic government. His opinion on forming such government has been presented in his book 'A Brief Discussion about Islamic government.' Although in the beginning this trend achieved some victories in Sine but such thought practically couldn't be suitable in Kurdistan's political sphere, though the domination of left and secularist thought on political groups. So, it was practically in contrary with important political parties of Kurdistan. In above-mentioned book, he presents his views on given Islamic government and its bases and characteristics. He is a strict opponent of secularism and mentions that:

...This anti people policy of separation of religion from politics gradually led to the conversion of the great and strong divine society to lethargic and idolatry... In recent centuries, i.e. since the shutdown of burners of Islamic civilization in Andalusia and from the time of Christians' attack from west and Mughol from East... the announcement of this sentence with the utmost frankness and boldness that 'Religion is separate from politics' and justification of this betrayal by fraud and deception methods -not by logic of force and despotism like past- is the product of this recent periods.... 
...The government is one of the human issues that Islam has appointed its total principles and laws that will never become old and functionless. And the humanity for ever needs to extract the rules of government from it anywhere and anytime... in this government, the scattered force of people is transferred to an organ or a body under the name of 'Showra' (council) that is similar with parliament in democratic countries. But [Showra] by its privileges makes Islamic government hundred percent democratic and popular, while none of the other parliaments in various systems have this power (Moftizada, 1980, 9-15).

In respect to nationalism issue, Moftizada theoretically believed in moderate approach and states: "Kurdish nationalism is one of the important political issues of region in recent century. The Iranian politicians (and also the politicians of other countries involved with the issue), in their stand on this issue, have always reduced this aspect and have condemned the possessor of this sense. While these diplomats, on the other extreme, change their stand and immensely supported the idea of nationalism outlined on the Iranism level. This method is not a special characteristic of single group. Indeed, keeping 'moderation' in human issues was, is and will be the most difficult human problem during history. And humanity including all classes, groups and nations has always involved with reductionism and extremism..." (ibid., 95). Despite this, he practically didn't regard this moderate aspect in relation with Kurdish nationalist forces, though understanding the political stand of Iranian nationalist. And, he adopted an extremist way for foundation of ideal Islamic government. Although it politically can be regarded as an attempt to attract the Sunni forces of other parts of Iran to stress on central government, nevertheless, on the other hand, he distanced himself from the important political forces in Kurdistan. So it just had an ideological (Islamic) justification not political logic.

Apart from above-mentioned issues, it should be noted that Maktab trend itself cause to a new internal religious cleavage in Kurdistan that it was in favor of centre. The new juridical view of Moftizada was in contrast with the traditional religious thought in Kurdistan. It provided a ground for centre's political use. In that sensitive situation for Kurds and especially with such social structure that there were various religious groups with enough potential for mobilizing against Maktab trend, by highlighting their different standpoint with other groups and the labels that were attributed to them, the forces of centre flared the internal religious contrasts.

\subsection{Maktab Trend and Conflict with Left}

As it was mentioned in the previous parts, the main ideological-political cleavage in Kurdistan during the revolution of 1979 in Iran, was between the Maktab trend and extremist leftists, where the stand of Maktab and on the top of it the Moftizada's stand clarifies this cleavage more. The office of Organization of Iranian People's Fadaiy Guerrillas in Sine reports on Moftizada as such;- “...He was not even the religious leader of Sanandaj, neither the leader of Iranian Sunni nor the Kurdish nation, yet he claimed for which is 'not left, not right, but Qur'anic pure Islam'. In this way he insulted and looked down the communists and non-Islamists, and sought for Islamic leadership in himself" (The Bloody War of Sanandaj..., 1979, 36). They also mention Moftizada as the main culprit in creating ideological conflicts, and reports that:

The next, was the issue of stick to hands on October 30 and the murder of people on October $31^{\text {st }}$ and culminating of the occurred movement which was then followed by arresting of people [involved in such great bloodshed.] In this course of time the first sitting of Jame mosque happened where the main activists were the youths of the left forces. Meanwhile, at that time General Ezhari was reigning his power under the strong anti-Marxist propaganda of government. Mofti in the Jame mosque objurgated the Marxists strongly. He batted the culminating of cooperation and collaboration of left and religious forces, which marked the beginning of the segregation of ranks within the people and gradually led to the deviation of the real mass and the religious fighters resulting in formation of the Jihad pray that they intended to capture the office of the supporters [of the organization]. In such a context, where the domination of imperialism and backwardness has not been eradicated entirely, the Marxist-Religious war rightly means the removing of the revolutionary force of people against Imperialism and backwardness. And any force who intend to extend this conflict, is regarded as a traitor to people and people's movement (ibid., 41).

Instead of maintaining the national pride and right of Kurdistan, Maktab was more inclined towards acquiring power and fame by competing with the left forces. And with the hope to accomplish its plan and to reinforce its status, it tried to take the help of the centre by covering the centre's shortcomings. While in its attempt to fulfill its plan, Maktab reinforced the conflict but it gradually ended up in favor of the centre. Moftizada in his letter to Bazergan, the then Prime Minister of the Provisional Government of Iran at that time, on March $18^{\text {th }} 1979$, states that: 
...If God helps [us] and these three brothers can gradually attain the executive affairs from other brothers [Khosrawi for governor of province, one as his deputy and Zarinehkafsh as governor of city], it will help in putting up the exceptional circumstances before referendum, where our forces in cities and villages propagate, the motivation and sympathies of leftists and other oppositions of Islamic government can be neutralized... unfortunately even here I don't have the opportunity to write because always I am busy (and further to explain the shortcomings and the mistakes of most top officials [of centre]!)... (ibid., 65).

Besides, in his speech in Husseinieh Ershad (1979) on the selection of Younesi as the governor of Kurdistan province, he says:

In those days, the state imposed us a person as the governor that I told, 'I know him'. He is from officers of Tudeh Party and he is dangerous here.... The governor of Kurdistan, Younesi, in short period could work in uniting the Marxist groups with all anti-revolutionary forces.... So you send an officer of Toudeh party, give him a mission to make a force to conspire against me, and to be in a line with me in Kurdistan and Sunni world! For what?... (Moftizada, 1979b).

However, the ground was gradually provided for domination of the forces who were the people with leftist backgrounds, especially after the Nawroz (March 18-22) 1979 war and also after the creation of the five members council including the lefts, in Sine. Even some innovations of Moftizada like launching the conference of autonomy in June, 1979 also couldn't change this process (An Exploration in Political Life..., 1985, 133). Along with the decline of the Maktab's influence after the Sine war, the left spectrum includes PDKI, Fadaiy guerillas, The Community for Defense of Liberty and Revolution, Sheikh Ezaddin and so on, were in upward move that they refused to participate in the conference (ibid., 168). All these are the effects of strong ideological conflict between the two left and religious trends. From the above discussions, we can clearly picture out the dividing function of religion instead of it playing the role of bringing solidarity in Kurdistan.

\subsection{Maktab Trend and Armed Struggle}

Before the discussion on relationship with central government, it is necessary to mention Moftizada's belief to arm and the evidences of Maktab's being armed during the Iranian revolution. In his speech at Sunni Central Council (ShMS) meeting on March 31 and April 1, 1981, he says:

...In Qezel Qal'eh, I became friend with some of the senior officials like Dr. Javad Bahonar...Talking with Bahonar, I told it was such a devastating loss of 15 thousand people in June 4-5, 1963 without any result, while if we fought militantly, with 14-15 thousand people, we could overthrow the regime. And after a lot of contemplation, I told him, there are Kurdish people familiar with weapons and guerrilla warfare, you prepare the people and I will send some Kurdish to train them with special armed skills, so that this fighting will be converted to a big armed fighting (ibid., 68).

Also after revolution's victory, the evidences show that Maktab Qur'an had desired for militarization during the early months of revolution. According to Fadaiy Guerillas' report, on March 17, 1979, Moftizada through a letter demanded weapons and ammunition from colonel Safary, the commander of Sine corps 28. Safary had outlined that delivery of weapon have to be with the agreement of representative of Imam, i.e. Safdary (a Shiite clergy and the founder of another revolutionary committee in Sine), and the chief of Staff. This response and gesture discouraged the Maktab's supporters and hurt their sentiments which led to the riot. On the other hand, Safdary was also under the pretext that he had heard Moftizada's forces sell the cartridges and he is afraid of using weapons against himself, so he didn't want to give those weapons and ammunition. And as a result of it, some of the Maktab's supporters protested against Safdary with threats and slogans assembling towards his office. The unresponsive nature of the Safdary's forces by marking the beginning of shutting, and reciprocally reaction by Maktab's forces and people, resulted in the five days war of Nawroz (The Bloody War of Sanandaj..., 1979, 43). In another letter to colonel Safary on March 17, 1979, Moftizada says: "Our guards (Pasdaran) preserve the security of city and region. Up to now our guards has taken various weapons from incompetence people and have given up to the army.... And now several times, in writing I request cartridge and equipment and we have announced that the rifle and pistols have no cartridge, but we hear exotic answers ..." (ibid., 68). Besides, the office of Fadaiy Guerillas reports that:

In the evening of March 18 with the beginning of battle between both forces of Moftizada and Safdary, the guards of Moftizada's jail released their posts and the prisoners escaped. Instead of that, the jail's guards fought with Safdary's office.... But before that night, Safdary himself had gone to garrison and issued jihad order against "Infidels of Sanandaj" and then by helicopter escaped towards Kermanshah (ibid., 47). 
After Sine city council election, Fuad Rohani, one of the Moftizada's followers and the first elected, in an interview, published in Kayhan newspaper on April 17, 1979, had said:

The disarmament of [Fadaiy] Guerillas is not true, before election we agreed that after determination of city council members, the offices will be removed and instead of them the city council's guards and police are settled. And now that the public passion has been aroused, we asked the Guerillas and the Community for Defense of Liberty and Revolution to exert this decision a few days earlier"(Khoshali, 2008).

In this respect, and in answering the question of Pars news agency's reporter about returning non-indigenous Guards Corps to their regions as one of the demands of demonstrators and strikers in the Kurdistan cities, quoted by Kayhan newspaper on November 5, 1979, Moftizada himself had said: "Most of the people who have high education are in the Guards Corps (Spahe Pasdaran) but the Sawak's agents also has influenced in this army doubtlessly. And gradually the non-indigenous guard corps must be replaced by indigenous guards, but now the situation of Kurdistan is disordered and this work must be carried out on its opportunity" (ibid.).

The above cases show the initial preparing of Maktab trend to become armed. While a few months later, they didn't accept the armed defense of Kurdistan's people against an imposed war. And they left the armed fighting and finally the political activity. Here, it should be noted that apart from the other reasons like economic poverty, illiteracy and non-awareness which led to the attraction of the very less educated people to Muslim Fighters Organization, while in contrary the maximum of educated people desired for the Kurdish parties, as well the Maktab's activities also had effect on forming this organization within the IRGC. Although later, Moftizada condemned this act of government by a proclamation and described it as a betrayal to the people (Note 6). Their initial interest in arming, the religious climax created in Kurdistan by them, then their political isolation, that used by the central government against Kurdish political forces, indirectly provided a ground to form Kurdish Muslim Fighters Organization. As Amini, himself, in the interview (2006) says: “... I don't deny the fact that a lot of them had cooperation with us before the forming of this organization, but after joining it and facing with our disagreement, they left and went."

So, the Government used the religious sphere created by Maktab as a weapon to weaken them with their own prey and also to attract individuals against other Kurdish parties. Although most of the people attracted by the Government were from traditional religious people, but Maktab was effective in providing such field.

\subsection{The Maktab and Central Government}

According to Moftizada, himself, before the revolution's victory an implied agreement had been taken between Ayatollah Khomeini and him about being raised as leader of Kurds. In an interview with Ayandegan newspaper on June 24 and July 1, 1979, in answering a question on hearing his name more than other Kurdish leaders in Radio and TV, and on the existence of any special agreement with the government, he says: "About the agreement, my answer is that in the strangulated and suffocated situation when Imam was in Najaf, we agreed and this agreement is the continuity of those agreements that there were in that time ..." (Khoshali, 2008). Besides, in an interview with Tehran Mosaver magazine, July 22, 1979, about his contact with Ayatollah Khomeini, he says: "Trough the clergies who had come and go to Iraq, I was in contact with Imam and I used his guidance and counseling"(ibid.).

Despite these, in one side, the central government didn't trust Moftizada, as Fadaiy Guerillas Organization reports:

After the collapse of despotism, when the people were busy with funeral of their martyrs, Moftizada formed his own Islamic Revolution Office. In the eve of February 11, he settled in office building of the Governor [of Kurdistan province] and his operational office started its work. And he tried to attain the power. He had various trips to Tehran, Qom, Sistan and Baluchistan, and Kermanshah that all of them were related to stability of his own power as leader of Kurds and leader of Sunnis. But for the stability of his power, there were lack of trust from the Government and Imam's committee towards his authority.... (The Bloody War of Sanandaj..., 1979, 42).

Besides, they mention:

They prevented his measures since the Government and Imam confirmed Mofti less than Safdary. And in spite of Moftizada's influence among people, the support of Government was more important for him and his ambitions didn't allow him to be non-absolute force or second force. Safdary and Moftizada contested in all fields. So each one had separate Guard and separate patrol officer and inspector and each one was striving to recruit more forces..." (ibid., 130). 
Apart from what is true and false, and also from the standpoint of Fadaiy Guerrillas, it can be understood that this view on Moftizada, i.e. distrust on him by the centre, is a dimension of question and it is often related to religious policy and central government's analysis on his religious activities that will be more explained in next part. But beside this, as already mentioned, the centre took its political use of religion and religious forces including Maktab trend (that Maktab trend directly or indirectly helped them to reach their aims). This point is highlighted more in Amini's words (2006) quoted on their relation with provisional government: “... We also didn't find out this truth soon because we were becoming a victim of this policy too, they wanted to have this use from the religious and revolutionary personality of Kak Ahmad and leading situation of Maktab Qur'an...."

On the other side, in the beginning, Moftizada trusted the centre so much and as well cooperated with them. One of the drawbacks of Moftizada's policy was providing ground and allowing Safdary to involve in Kurdistan religious-social politics, who was in fact the sole creator of many issues in Kurdistan. Indeed, if he had a realist view and also adopted a nationality-oriented policy, he would have never trusted such a person. In an interview with correspondent of 'Javan' magazine, No. 23, he says on Safdary: "When I gave a way to Safdary before 15 months of the downfall of [King] regime; he was really a brave and faithful fighter ... when I understood that he doesn't know what he practically does ... I clearly told him, Mr. Safdary because of your one and half year fighting you are respected, but now you are useless, there is no place for you [in Kurdistan] ... then I didn't give a way to him" (An Exploration in Political Life..., 1985, 89). In his words, Safdary is responsible for the Nawroz war (March 18-22, 1979) in Sine and says: "The main factor of this event was a person, namely Safdary, and non-logical method of corps commander" (ibid., 91).

Another example of Maktab's trust to government, in contrary with other Kurdish Parties (PDKI and so on), was the participation in referendum of April 1, 1979 and voting for Islamic Republic in encouraging for inviting people to participate by announcement of March 25, 1979. Besides, according to the report of Pars news agency, quoted by Kayhan Newspaper on October 8, 1979, Moftizada after several months of people's demonstration in Sine, sent a telephone message from Tehran to Sine that was broadcasted at Radio Sine and awarded people of Sine to avoid any demonstrations, because of advent of anti-revolutionary forces. He refused the rumor of his residence in Tehran and announced during the 20 days in Tehran he was busy with reviewing the economic affairs in No. 7 commission of Experts Assembly (though he was not an economist) and returns to Sine in coming days (Blouri, 2004). Moftizada as a single invited person by Ayatollah Montazeri, the speaker of the assembly, participated in it without selecting (he had resigned from candidacy). While some of the Kurdish selected representatives as Abdul-Rahman Qasemlu was prevented to enter the assembly. And also in the speeches of the assembly, the Kurdish people were attacked. So it was another dimension of his personal relationship with centre. Because of these reasons, someone like Nadir Intisar introduces him as a supporter of Islamic Republic and compassionate of Iranian theocracy (Intisar, 2003, 12). Indeed, the politicians of centre only used him as a representative of the Kurdish and Sunni politics to obtain legitimacy for the assembly.

Amini's words (2006) also disclose Mofti's nature of over-reliance. In response to a question on selecting Younesi as the governor of Kurdistan, he says: "As a truth, it is better for all to know that Mr. Moftizada, because of his vigorous religious interest, had gone through a lot of sufferings and pains together with his fellow citizens and also his compatriots from Shahanshahi (king) regime, hoping for an Islamic revolutionary beyond imagination. As a result of it he wanted to leave everything except Islam and Kurdish nation. He never wanted to defile the [Iranian] revolution and its dignity. Hence, the selecting of Mr. Younesi as a first governor of Islamic Republic in Kurdistan [province] surprised all of us." This over-reliance had a negative effect on his followers and the political space of Kurdistan so that the Coordinating Council of Sine Islamic Communities via a telegraph to Ayatollah Khomeini, published in Islamic Republic newspaper on August 21, 1979, announcing Moftizada as their leader in Kurdistan and Ayatollah Khomeini as super leader of Islamic revolution, supported Ayatollah's order to attack Kurdistan. They also called Kurdistan as a captive in the foul clutches of Sawak, Fadaiy, Feudal and Democrat, which by this attack will be rescued (Khoshali, 2008).

The disappointment derived from Moftizada's over-reliance to centre and centre's using of him is more evident when Moftizada in his speech in Hosseiniyeh Ershad in 1979 says: “...Maybe you also know that we were the only force who preserved Kurdistan." Hence, there was a two dimensional relationship with centre, where the first dimension of the relation was the lack of centre's trust to Maktab trend and its leader, and on the contrary the second dimension is related to the optimistic trust of the trend to centre. So the Government took a necessary use and the Maktab trend despaired in reaching to mental and unrealistic ideals.

\subsection{The Maktab and Political Isolation}

Before drawing to conclusion, it is necessary to be clear that, despite of the victory of Maktab in the local 
council election of Sine city on April 13, 1979 (3 elected from left forces and 8 elected from religious), the political activities of this trend continued only for a short period of time and got isolated. Indeed, this Islamic trend had no practical strategy and tactics to enliven the Kurdistan nationality. If there is a strategy, the behaviors and actions manifested in it, should reflect and yield changes both in political and logical way, which can be interpretable and will match the defined plan. But the behavior and action of Maktab often was a series of daily reflections and reactions. Although beyond the issues related to Kurdistan, Moftizada's idealist main program and strategy ought to continue for years and not be practiced, but the revolution's victory canceled the program and before its real time, he had unsuccessful attempt to form given Islamic government in Iran.

In political issues, the Islamists often sensed themselves as an obstacle against the leftists. Thus, practically they didn't regard the 'nationality' as a common aspect with other Kurdish forces. While the new Kurdish movement, was often affected by the left movement. But in contrary, the most of leftist Kurds considered the 'Nationality' aspect. Moftizada's monopolism and his non-cooperation with Kurdish forces were not, somehow, in the line of solving the national problem. For example, when Sheikh Ezzadin Husseini was selected as a speaker of Provisional Revolutionary Council on March 20, 1979 in Sine and a five articles resolution was drafted for ceasefire, even Moftizada was a part of the alliance, in the mid-night a meeting including Sheikh Ezzadin and Provisional Revolutionary Council, Sarim Al-din Sadeghwaziri and Moftizada was held. In the meeting, Moftizada preferred the three articles plan of Seqiz in comparison with eight articles plan of Mahabad and didn't accept company with the council to present a common plan to government and the group of Ayatollah Taleghani. So at 4am, he left the session. In the morning, he went alone to Mr. Taleghani (The Bloody War of Sanandaj..., 1979, 51).

In contrary, for example, in murder of Nawroz 1979 in Sine, Sidegh Kamangar and Mozafar Mohammadi (of the leaders of the Community for Defense of Liberty and Revolution in that time) supported and accompanied with Moftizada. They issued an announcement in March 20, 1979 and announced Safdary as a factor of the murder of Nawroz (An Exploration in Political Life..., 1985, 93). Indeed, Maktab trend did not want to accept to be at a line with leftists. On the other hand, the sheer disappointment from centre, despite of their dependency from the initial stage, left them with no motivation and ability to envisage with other political parties. So this situation led them to retreat from the scene of political power despite of their victory in the above mentioned election. The lack of program in comparison with the relative organization of left trends, lack of political understanding and just relying on religious-populist politics, led to their isolation and putting in bottleneck.

In this respect and in explaining the reason of political conflict in Sine in March 1979, Amini (2006) says: "...One of the important factors was the vesting of the garrison and other formal and old armed forces to Mr. Safdary, a non Kurdish and non Sunni [...]. They don't regard the jihadists, and overthrow the right people like Moftizada with all the fighting and attempts that he underwent and led to the victory of revolution. They don't consider him and his opinion in the key and important issues, even in Kurdistan ...." It was another sign of centre's distrust. So the Maktab trend had to discard the confrontation and had become approach to other Kurdish forces since they were aware on this subject. But paying more attention to the religious issues isolated themselves from both sides, i.e. the centre and Kurdish forces. As he also mentions that: “... Another factor was the fear of non-religious forces from setting of religious sovereignty that they used any tools to disgrace religion and to make people dissatisfied. In Kurdistan, this field was provided by friends more than enemies! ...." Besides, in explaining the terrors and militarizing the parties, Amini says:

... The most important factor for leaving Sanandaj and the migration to Kermanshah, was the problem of militarizing of non-Islamic parties and groups in Kurdistan, because unfortunately they had targeted us more and earlier [than others]... In the last sermon Friday before leaving Sanandaj, Moftizadeh exactly had mentioned this issue and factor: 'Because of avoiding fratricide among Kurdish people and under Islam and non-Islam, and while the [other] Kurdish groups and persons are non-Muslim and our side are Muslims, still the decisive reason has not been completed for us to invite to fight with them, so I leave Kurdistan [province] and anybody who follow me, do this work, because though we don't want to kill them, they will kill us.'

But as it was mentioned, the evidences show that the ideological conflict with left forces was the reason that had put them in front of together. As also mentioned before, about the militarization, Maktab had some plans to be militarized in the beginning and they had armed people but they only wanted the right of militarizing for themselves not others. So there was a war to obtain power between religious and non-religious groups, that Maktab eventually retreated and preferred isolation. The problem of capturing power and use of 'divide and rule' policy by centre is shown in Moftizada's letter to Bazergan on April 8, 1979 within which he called Kurdish forces as enemy. He writes: “... we were absolute political and military power existed in the region, but the 
leadership organization [of revolution in centre] with its bad policies led to the loss of our militant and political power to the enemy [other Kurdish parties] which almost isolated us, and it was the work of the government itself, otherwise no enemy could to do this (maybe there will be an opportunity and if you want I narrate the event)..." (The Bloody War of Sanandaj..., 1979, 209).

In the speech of Husseinieh Ershad at September 1979, Moftizada says: “... I told Imam that this revolution is going in the recessive path, I truly told him that the revolution is not Islamic any more. It is recessive. It collapsed. I told, it is necessary that I struggle with the revolution but in favor of this Muslim nation I don't fight..." (Moftizada, 1979b). It shows that the Islamic aspect and being Muslim was important for him so they were isolated. While concerning nationality-oriented policy, it was better to join the other Kurdish political groups and organizations, and at least as an independent group participated in nationalist activities beside them. In the declaration of Moftizada's motivation for leaving Kurdistan province on August 12, 1980, it is mentioned that: "This time also for preventing the bloodshed of thousands of Muslims and civil war in Kurdistan, we thought on a solution and ordered the Muslims, who were identified and hated by mercenaries because of their struggles during previous regime and they couldn't be indifferent against the enemy of people, to leave Kurdistan [province]" (An Exploration in Political Life..., 1985, 120).

Eventually, the arresting and repression of Maktab's forces by government was further because of religious-political reasons not ethno-political. Although no evidence of proof and document had been presented to show the dependency of 'Sunni Central Council' (ShMS) to Sudia Arabia and following the Taif conference resolutions (a part from the attendance of Moftizada's representatives in it) and so on, but one of the special reasons for arresting him and some of his colleagues was due to the foundation of the council and the analysis of governmental officials at that time. From the government's viewpoint, the council was an executive arm of Taif Conference in Iran and they analyzed its existential philosophy as following the Arab recessive intentions in directing the religious conflicts (ibid., 182). Hence, the arresting of the Maktab's members and the debacle of their revealed activities was not because of national (Kurdish) issues. It was for religious conflicts. And it divulged the weak of religion-oriented policy which resulted in political isolation.

\section{Conclusion}

A one-sided view on national identity, on one hand, and inharmonic emphasis on religious and spiritual element to the detriment of the national element, on the other, has a bad political, cultural and identity consequences and it endangers the traditional societies. This is what was experienced in Kurdistan in the early years of 1979 revolution. The growth of political Islam in Middle East and its influence in Iran and consequently the extension of ideological conflict between Islam and Marxism in the region especially in Kurdistan strongly, led to the conflict among political actors in Kurdistan, directly and indirectly. It was ended in the detriment of Kurdish nationalism since Kurdistan politics is related to nationalism more than other things. So, nationalism was important more than religion and left ideology for unity and solidarity in Kurdistan. Although Islam and left ideology are the factors to unite people of different background together that can be possibly used in channeling them out in the line of nationalism but it didn't worked out in their political scenario.

The examining of the events of that time shows both positive and negative political functions of religion in Kurdistan. It was more negative for Kurdish movement as a divisive factor. On the other side, religion became a political tool with positive function in the hand of central government. Religion was used to denigrate opponent groups and more than others, it was a divisive factor among political groups because of contesting with left ideology and so on. So, indeed, Kurdistan became the victim of ideological conflict. Hence, totally, it should be noted that the new Kurdish national movement never could use religion in favor of national solidarity like other nations. Maybe the Kurdish nation is the only nation where its religion was used as a means of its suppression, especially as a tool to different types of genocide.

In Kurdistan, religion not only could unite religious people but was also used against the solidarity of other beliefs specially nationalism. Besides, communist ideology completed this negative role of religion by providing a ground to religious reaction and motivating mass sensations. Indeed, both of them segmented the people and had a divisive role. These ideologies and their functions, intentionally or unintentionally, consciously or unconsciously, instead of serving themselves, helped the central government's interest. Kurdish nationalism was the only common factor among the three main political trends (nationalist, left and religious) to bringing solidarity among them, but it was ignored and became the victim of ideological conflict.

Maktab Qur'an as the most effective religious trend and one of the representatives of political Islam in Kurdistan during Iranian Revolution, involved in political traps badly. In spite of having the idea of establishing an ideal Islamic government for Iran without regarding any special sect, it indeed didn't have any necessitous tactics and 
well modeled strategy to apply in the context of Kurdistan. Despite the nationalist streaks within it, religion was a dominant factor in Maktab trend and their ideological behavior led to the lack of understanding their political situation. This approach itself was under the effect of Islamic trends of the countries that had passed the nationalist stage. Therefore, on one hand, the optimist relationship, and their initial unilateral and unequal trust to centre and, on the other hand, their political and ideological stance against left forces then cutting out from centre and also not joining to other political forces (at least moderate forces) in Kurdistan, not only led to Maktab's political isolation but also practically led to remove themselves as a political actor and also centre's political use of religion against other forces. However, they could have played a better role and would have had a maximum use of political function of religion.

\section{References}

A Castle of Will, a World of Faith (2003). An interview with Mamosta Abdulrahman Lahijani (to memorial of his death). First edition. PDKI's Social Commission Publication.

Ahmadi, H. (2006). Religion and Nationality in Iran: Conflict or Cooperation? In H. Ahmadi (Ed.), Iran: Identity, Nationality and Ethnicity. Tehran: The Institution of Research and Development of Human Sciences.

An Exploration in Political Life of Moftizadeh (1985, April). A study conducted by the Educational Affairs of Kurdistan Province.

Blouri, M. (2004). The Command of Attack to Kurdistan by Khomeini, the Three Months War in Kurdistan from August 18 to November 17, 1979. Second part. Retrieved from Http:/Www.Kurdistansite.Com

Hamilton, M. (2001).The Sociology of Religion (2nd Ed.). New York: Routledge.

Interview with Hasan Amini. (2006, Fall). Chashmandaz magazine, Special issue of 'Kurdistan Is Always Detectable', No. 2, P. 33.

Intisar, N. (2003). Kurdish Ethno-Nationality. Translated into Kurdish by Ata Qaradaghi. Slemani: Qane Publication.

Kochera, C. (1999). Kurdish Defiance. Translated by Aso Hasanzada. Serbexo Publication.

Kochera, C. (2000). The Movement of Kurdish Nation and the Will of Independence. Translated by Aziz Mamele. No place.

Khoshali, B. (2008). Kurdistan, the Crisis Days, Press Documents (Kurdistan News), 1979-1981. Retrieved February 2, 2015, from Http://Www. Iran-Archive.Com/Start/215

Mofidi, S. (2005, February 26). The Kurdish Religious Character and the Complex World of Politics (in Kurdish). Aso Weekly, (86), 6.

Moftizada, A. (1979a). Handwriting of 'I and Revolution. 'Iran: No city.

Moftizada, A. (1979b). The lecture cassette tape in Husseinieh Ershad. Tehran.

Moftizada, A. (1980). A Brief Discussion about Islamic Government. Sanandaj.

Moftizada, A. (N. D.). About Kurdistan. Iran: No city.

Qasemlu, A. (2004). Tavgay Hagheghat (Waterfall of Truth), A part of Dr. Qasemlu's works. Compiled by Kawa Bahrami. Volume I. Iraq: No city. PDKI's Publication.

Sheikh Attar, A. (2002). Religion and Politics: The Case of India. Tehran: Foreign Ministry Publication.

The Bloody War of Sanandaj and Its Result, City Council (1979). Sanandaj. The Office of Supporters of Organization of Iranian People's Fadaiy Guerrillas.

The Constitution of 'Islamic Musawat Party.' March 6, 1979.

The Untold of Kurdistan in the Word of Foreign Minister of Provisional Government (2005, March 14). An interview with Dr. Ibrahim Yazdi. Ashti Newspaper, Second Year, No. 22.

\section{Notes}

Note 1. The J.K party, ‘Komeley Jiyanewey Kurdistan’ (Revival of Kurdistan Party) in Kurdish, was proclaimed in 1942 .

Note 2. In Iran it is called 'Sazmane Pishmargane Mulasmane Kurd' (Kurdish Muslim Peshmarga Organization).

Note 3. In Iran it is called 'Sepah-e Pasdaran-e Enghlabe Eslami-e Iran' (in Persian). 
Note 4. In Persian, his name is written as 'Ahmad Moftizadeh'.

Note 5. For example, in Indian subcontinent (under the effect of Islamic thinkers like Iqbal, Abu Ala Mawdoodi and others) and Arab countries (under the effect of Rashid Reza, the Syrian Islamic thinker, and others), firstly Islam, nationalism and statism were composed but later the constructed states opposed with other kinds of nationalist trends by Islam as a tool.

Note 6. Recently, it was heard from a source that later on Moftizada through an announcement condemned the forming of Kurdish Muslim Peshmarga Organization and announced it as betrayal of the people, but the announcement was not found by the writer up to now. Perhaps when Moftizada was discouraged from the central government and understood that this force is out of his power, and the government abuse it, decided to announce it.

\section{Copyrights}

Copyright for this article is retained by the author(s), with first publication rights granted to the journal.

This is an open-access article distributed under the terms and conditions of the Creative Commons Attribution license (http://creativecommons.org/licenses/by/3.0/). 